\title{
COUMARINS OF Cicuta virosa
}

V. A. Makarova, A. P. Prokopenko,

UDC $547: 597$

G. A. Zhukov, and E. Ya. Ladygina

Cicuta virosa L. (European water hemlock), family Umbelliferae, is a widely distributed water-loving plant [1]. Various parts of it are used in folk medicine for the treatment of chronic skin diseases, rheumatism, etc. [2]. Many cases of the poisoning of humans and animals by C. virosa have been reported in the literature. The poisonous properties of this plant are due to the polyacetylenic compounds, which have been isolated and investigated previously [3], but on the whole its chemical composition has been studied inadequately.

A preliminary chromatographic investigation of all the parts of the plant showed the presence in them of substances of a coumarin nature. To determine the coumarin composition, the fruit of C. virosa collected in August, 1971, in the Moscow area was used. Paper chromatography in the chloroform-formamide system (I) and in a thin layer of "acid" alumina in the ethyl acetate-chloroform-cyclohexane (2:1:7) system (II) showed the presence of two coumarin compounds (I with $\mathrm{R}_{f} 0.5$ and 0.74 ; II with $\mathrm{R}_{f}$ 0.31 and 0.38 ). To isolate these substances, an evaporated ethanolic extract of the fruit was treated with chloroform, and the chloroform extract was concentrated and deposited on a column of alumina (activity grade II). The column was eluted with chloroform until two zones appeared having a blue fluorescence in UV light. The zones were cut out, and the substances adsorbed on them were eluted by heating with $96 \%$ ethanol. The eluates yielded two substances $\left(\mathrm{C}_{9} \mathrm{H}_{6} \mathrm{O}_{3}\right.$, with $\mathrm{mp} 234-235^{\circ} \mathrm{C}$, and $\mathrm{C}_{10} \mathrm{H}_{8} \mathrm{O}_{4}$, with $\left.\mathrm{mp} 205^{\circ} \mathrm{C}\right)$.

From their $R_{f}$ values on paper and in a thin layer of "acid" alumina in comparison with authentic samples, the absence of depressions of the melting points of mixed samples, and also from their physicochemical properties ( $\mathrm{mp}$, elementary composition, UV spectra), the compounds isolated were identified as 7-hydroxycoumarin (umbelliferone) and 7-hydroxy-6-methoxycoumarin (scopoletin).

This is the first time that umbelliferone and scopoletin have been isolated from $\underline{\text { C. virosa. }}$

\section{LITERATURE CITED}

1. Flora of the USSR [in Russian], Moscow-Leningrad, XVI (1950), p. 376.

2. V. G. Minaeva, Medicinal Plants of Siberia [in Russian], Novosibirsk (1970), p. 53.

3. A. Anet, B. Lythgoe, M. Silk, and S. Trippett, J. Chem. Soc., 309 (1953).

I. M. Sechenov First Moscow Medical Institute. Translated from Khimiya Prirodnykh Soedinenii, No. 1, pp. 112-113, January-February, 1973. Original article submitted July 13, 1972.

- 1975 Consultants Bureau, a division of Plenum Publishing Corporation, 227 West 17th Street, New York, N. Y. 10011. No part of this publication may be reproduced, stored in a retrieval system, or transmitted, in any form or by any means, electronic, mechanical, photocopying, microfilming, recording or otherwise, without written permission of the publisher. A copy of this article is available from the publisher for $\$ 15.00$. 